\title{
Synovial fluid lubrication: The effect of protein interactions on adsorbed and lubricating films
}

\author{
Maria Parkes, Connor Myant, Philippa M. Cann and Janet S.S. Wong* \\ Tribology Group, Department of Mechanical Engineering, Imperial College London, SW7 2AZ \\ London, UK \\ *corresponding author
}

\begin{abstract}
Synovial fluid lubrication is dependent on protective protein films that form between joint surfaces. Under static conditions surface film formation occurs through adsorption, whilst under dynamic conditions protein aggregation under shear and load becomes the dominant mechanism. This work examines how the protein content of six model synovial fluids affects film formation under static and rolling conditions and if the changes in properties can be correlated. With an increase in the statically adsorbed mass and the rate of adsorption, the film thickness under rolling increased. These increases did not correlate with the total protein content of the fluid, but were dependent on the type of protein. An increase in $\mathrm{pH}$, reduced the adsorbed mass, rate of adsorption and film thickness, but was of secondary importance to the type of protein. The rolling film thickness was also correlated with the viscoelastic properties of the films formed under static conditions. In this case thinner rolling films corresponded to the more hydrated, viscoelastic adsorbed films.
\end{abstract}

The strong correlations found between the properties of the adsorbed films and those formed under rolling indicate that the same protein-protein and protein-surface interactions may govern both mechanisms of film formation despite the differences in the film structures.

\section{Introduction}

Total hip replacement is an extremely successful operation, with $82 \%$ of implants lasting 10 years or more [1]. For younger patients which account for 8000 total hip replacements in the UK each year, this number drops to $72 \%$ [2]. Consequently there is a need to improve the current joint designs to meet the demands of some patients. Looking to the future, the number of joint replacements performed around the world increases year on year, a trend which is set to continue [3]. The growth in demand far outstrips the growth in healthcare budgets, and so it is inevitable that there will be a need for cheaper implants, which may well dictate the use of new materials, manufacturing processes and designs. The recent problems with the metal-on-metal systems, where excessive wear and tribocorrosion have led to recall of implants highlight the importance of understanding the tribology, and hence lubrication of new systems at the outset. 
A human hip joint can be represented by two surfaces rubbing against each other, separated by the natural lubricant which is synovial fluid (SF). This fluid is a complex mixture of macromolecules with a large concentration of plasma proteins which demonstrates non-Newtonian behaviour $[4,5]$. The properties of the fluid, including $\mathrm{pH}$ and protein content vary from patient to patient, and between healthy and diseased states [6,7]. As such the classic models for predicting film thickness developed for simple hydrocarbons, with consistent fluid properties cannot be used to estimate the lubricant thickness separating the rubbing joint surfaces [8]. This greatly limits our ability to design new improved, endurable implant systems. To tackle this shortcoming, the authors have conducted in-situ measurements of lubricating films, to provide insights on lubricating (or protective) film formation mechanisms on rubbing surfaces in fluids with high protein concentrations $[5,8,9]$.

Visualisation of the tribological contact lubricated with model SF has highlighted a new mechanism of SF lubrication: Protein Aggregation Lubrication (PAL) $[8,9]$. This occurs in protein solutions at low speeds, where a local region of increased protein concentration occurs at the inlet to the contact. Proteins trapped at the inlet form large aggregates which are pulled into the contact, separating the surfaces. In previous studies the authors have shown in Saline and Tris- $\mathrm{HCl}$ solutions that this mechanism is influenced by the type of protein as well as the total concentration of protein in the fluid $[10,11]$. This work also demonstrated that bovine calf serum (BCS) solutions, which contain a mixture of the proteins albumin and gamma-globulin, form thinner films than solutions of only gamma-globulin. This implies that interactions among proteins in BCS impact on the formation of lubricating films. Subsequent studies by Vrbka et al. [12-14] have highlighted the role of the protein-surface interaction in the formation of PAL films. They found thicker films forming on CoCrMo surfaces compared to ceramic alumina surfaces [12], and that thinner films are formed on more hydrophilic surfaces [13]. Studies of protein adsorption can provide information about protein-surface interactions, and so will be useful in understanding the formation of lubricating films.

Protein adsorption at surfaces, biolubrication aside, is also of importance in many scientific and technology areas for example food industry and bio-fouling and there is an extensive body of research literature on the subject. Adsorption of the proteins albumin and gamma-globulin, both independently and together have been investigated under static conditions using techniques such as quartz crystal microbalance (QCM) [15,16], fluorescence imaging [17], ellipsometry [18,19] and surface plasmon resonance spectroscopy [20]. These studies show that competition between the proteins for adsorption sites can affect the mass, thickness and viscoelastic properties of the adsorbed layers. These properties are dependent on relative protein concentrations and protein-surface interactions, which can be affected by $\mathrm{pH}$ and chemistry of model SFs. Note many of the studies [15-19,21-24] have been carried out at relatively low protein concentrations, typically $0.01-1 \mathrm{mg} \mathrm{ml}^{-1}$. At the concentrations relevant to synovial fluid $\left(7-18 \mathrm{mg} \mathrm{ml}^{-1}\right.$ for albumin and 0.5-2.9 for gamma globulin [25]) the impact of competitive adsorption among SF proteins on the adsorbed film properties is not known. Furthermore, the relationship between properties of adsorbed film and those of films formed through protein aggregation is not established.

The two key questions addressed in the work were: 
1. What are the effects of the protein content and $\mathrm{pH}$ of model synovial fluids on adsorption and PAL film formation on silica and chromium surfaces?

2. Can static adsorption results be used to predict the properties of lubricating films formed through PAL?

In this study, the relationship between statically adsorbed protein films and lubricating film formed when rubbing surfaces are in relative motion was investigated for films formed in a range of model synovial fluids. Although this is not a direct simulation of a hip joint, the model fluids, test surfaces, speeds and contact pressures were chosen to be similar to a metal on metal (CoCrMo) joint system. Model synovial fluids were prepared using bovine serum albumin (BSA), bovine gamma-globulin (BGG), and a mixture of these proteins at either $\mathrm{pH} 7.4$ or $\mathrm{pH} 8.1$ to represent changes between healthy and diseased fluids. A quartz crystal microbalance (QCM) and a ball-on-flat device were used to examine properties of statically adsorbed films and lubricating films (see sections 2.2 and 2.3). For QCM quartz crystal with either a silica or chromium coating were used, whilst under rolling a flat silica surface and a CoCrMo ball were used. The silica surface was required to conduct optical measurements, but is similar to the ceramic alumina $\left(\mathrm{Al}_{2} \mathrm{O}_{3}\right)$ used for hip prosthesis in that both surfaces have a low surface roughness $<10 \mathrm{~nm}$ [26], are hydrophilic and are charged [12]. There is however, a significant difference in that silica and alumina negatively and positively charged respectively in the relevant $\mathrm{pH}$ range [27]. A chromium coated crystal was used in QCM to represent the CoCrMo alloy used in rolling tests. This crystal has a surface layer of hydrophilic chromium oxide $\mathrm{Cr}_{2} \mathrm{O}_{3}$, which correspond to the primary oxide found on the surface of CoCrMo implants $[28,29]$.

\section{Materials and Methods}

Using a QCM the adsorption of BSA and BGG on silica and chromium surfaces was examined at $\mathrm{pH}$ 7.4 and 8.1. The effect of protein content on lubricant film thickness was then examined for a silica/CoCrMo interface using optical interferometry under a pure rolling condition.

\subsection{Solutions}

The composition of all test solutions is given in Table 1. Tris Saline buffer was used to prepare all solutions so that changes in buffer chemistry did not impact the results [5]. Tris saline was prepared at a concentration of $10 \mathrm{mM}$ 2-amino-2-(hydroxymethyl)-1,3-propanediol (Tris) (SigmaAldrich, T-87602) in ultrapure Milli- $Q$ water (resistance $>18 \mathrm{M} \Omega \mathrm{cm}$ ), with the addition of sodium chloride $(\mathrm{NaCl})$ (analytical grade, VWR, 27810) to reach a physiological ionic strength of $154 \mathrm{mM}$. The pH was adjusted using sodium hydroxide $(\mathrm{NaOH})(\mathrm{VWR}, 28244.262)$ or hydrogen chloride $(\mathrm{HCl})(\mathrm{VWR}$, 20252.335 ) as necessary to either $\mathrm{pH} 7.4$ or 8.1 representing healthy or diseased synovial fluid respectively [6].

BSA (Sigma Aldrich, A7906, $\geq 98 \%$ agarose gel electrophoresis, lyophilized powder) and BGG (Sigma Aldrich, G5009, $\geq 99 \%$ agarose gel electrophoresis), were used without further purification. The concentrations of BSA and BGG were fixed at $10 \mathrm{mg} \mathrm{ml}^{-1}$ and $2.4 \mathrm{mg} \mathrm{ml}^{-1}$ which is within the physiological range for these proteins in healthy synovial fluid [30]. 


\subsection{Adsorption measurements with quartz crystal microbalance (QCM)}

The dynamics of protein adsorption and the nature of the adsorbed film were investigated by QCM. A QCM uses a quartz crystal that is electrically stimulated to oscillate at its resonant frequency. The adsorption of proteins increases the mass of the crystal and so changes its resonant frequency (frequency shift, $\Delta f$ ). Adsorbed protein films are known to contain water and ions and as a consequence it may not be a perfectly rigid film and can demonstrate significant viscoelasticity [31]. This creates a further frequency shift due to energy dissipation in the protein film which is termed 'viscous loading' of the crystal.

\subsubsection{QCM theory}

The total measured frequency shift, $\Delta f$ is a linear combination of the frequency shift due to the mass loading, $\Delta f_{\text {mass }}$ and the viscous loading $\Delta f_{\text {viscous }}[32,33]$ such that:

$$
\Delta f=\Delta f_{\text {mass }}+\Delta f_{\text {viscous }}
$$

If only $\Delta f$ is measured the relative contributions of the mass loading and viscous loading to the total frequency shift cannot be separated [32]. To separate the mass and viscous (dissipative) effects, the change in motional resistance, $\Delta R$, of the crystal is monitored. $\Delta R$ is independent of mass loading but dependent on viscous loading [33] such that:

$$
\Delta R=K_{1}\left(\rho_{l} \eta_{l}\right)^{1 / 2}
$$

and

$$
\Delta f_{\text {viscous }}=K_{2} \Delta R
$$

where $K_{1}$ and $K_{2}$ are constants dependent on the quartz crystal properties, $\rho_{l}$ is the density of the liquid and $\eta_{l}$ is the viscosity of the liquid. For a $5 \mathrm{MHz}$ crystal the value of $K_{2}$ is $-2 \mathrm{~Hz} \Omega^{-1}$ [33]. This can be applied to give a real-time correction for the viscous loading [33] with the change in frequency due to mass alone calculated as:

$$
\Delta f_{\text {mass }}=\Delta f-K_{2} \Delta R
$$

The relative importance of adsorbed mass over viscous effects is indicated by the absolute value of the ratio $\Delta R / \Delta f$, with a smaller ratio indicating a dominance of the elastic mass effect [34]. Details of the above analysis can be found in [5].

\subsubsection{Protein Adsorption under static conditions}

Prior to each experiment the crystals and flow cell were cleaned separately. The flow cell was sonicated for 15 mins in 2\% detergent solution (Decon 90, VWR), followed by Milli-Q water, then 
isopropanol and then dried with nitrogen. Just before use crystals were treated for 10 minutes in air plasma.

$5 \mathrm{MHz}$ Quartz crystals (Testbourne Ltd, UK) were mounted in a liquid flow cell, as shown in Figure 1. The flow rate was controlled at $60 \mu \mathrm{min}^{-1}$ using a MilliGAT Pump (Global FIA, USA). Measurements of adsorption from protein solutions were taken for 30 minutes, before the flow cell was rinsed with buffer. Measurements were taken at room temperature $\left(20^{\circ} \mathrm{C}\right)$. The lower than body temperature condition will slow slightly the rate of adsorption, with no expected change to the final adsorbed amount [29]. The variations of frequency $(\Delta f)$ and resistance $(\Delta R)$ of the crystal were monitored as a function of time, during the sequential addition of buffer (baseline), protein solution and buffer again (rinsing), to the liquid flow cell.

\subsection{Film thickness measurements in a rolling contact}

Film thickness measurements of protein solutions in a rolling contact were made with thin film optical interferometry using a ball-on-flat device and a spectrometer (Ultra-Thin Film EHL, PCS instruments UK). Further details of the technique are provided in [35]. The CoCrMo ball had a diameter of $19 \mathrm{~mm}$ and an average surface roughness of $10 \mathrm{~nm}$ as measured by optical interferometry. The test conditions used for film thickness measurements are given in Table 2. The mean contact pressure was $200 \mathrm{MPa}$, which corresponds to the higher than average contact pressures seen in misaligned or edge loaded metal on metal joints $[36,37]$. A pure rolling condition was chosen here although this is not representative of motion in hip joints which is pure sliding. Rolling was chosen to reduce the surface wear that occurs in sliding and so the effects of wear and film formation could be decoupled. Sliding wear also damages surfaces making optical interferometry measurements more difficult. Under rolling conditions, the surface films and lubricating fluid still experience shear stresses and loading, which have been highlighted as important factors in protein lubrication [21]. The test temperature was $20^{\circ} \mathrm{C}$ to be consistent with QCM measurements. This reduces evaporation of the lubricant during testing.

A schematic of the test rig is shown in Figure 2. The well was filled with test solution so that the ball was more than half submerged in the test fluid throughout the test. Extra fluid was then introduced into the contact using a syringe to form a meniscus around the contact area which was maintained throughout the test. This method has been used in several published works $[5,9,11]$ and is not expected to affect film thickness results.

The two contact surfaces were initially separated and the test fluid added, allowing static adsorption to proceed as in the QCM experiments. After 1200 seconds, the contact was loaded to $5 \mathrm{~N}$ and the adsorbed thickness for the static contact $h_{t=0}$ measured.

Following static adsorption the ball and disc were both rotated at $10 \mathrm{~mm} / \mathrm{s}$ to generate pure rolling in the contact. This speed is within the range of speeds experienced during a gait cycle [33], and ensures boundary lubrication occurs. The film thickness was recorded as a function of time during rolling, for a total of 1200 seconds. At $t=1200$ seconds, the thickness of the film is labelled as $h_{t=1200}$. 
At the end of rolling, the contact was unloaded and separated, and immediately reloaded to $5 \mathrm{~N}$, the residual film in the statically loaded contact was measured giving $h_{\text {final. }}$. Following the test both surfaces were lightly rinsed with water and examined dry with an optical microscope.

For visualisation of the rolling contact, a CCD camera was used in place of the spectrometer. For each rotation an image was taken at approximately the same point on the disc so that a set of images corresponding to a set of film thickness measurements is recorded.

\section{Results and Discussion}

\subsection{Protein absorption under static conditions}

The change in resonance frequency of the silica and chromium coated quartz crystals due to the mass of protein absorbed on their surfaces, $\Delta f_{\text {mass }}$, is presented in Figure 3 for all protein solutions. The maximum rate of mass adsorption, final adsorbed mass and $\Delta R / \Delta f$ (after rinsing) in each solution are given in Table 3 .

\subsubsection{Protein layer formed in single protein, BSA solutions and BGG solutions}

While the concentration of BGG and BSA in single protein solutions is $2.4 \mathrm{mg} / \mathrm{ml}$ and $10 \mathrm{mg} / \mathrm{ml}$ respectively (see Table 1), more BGG is adsorbed in all cases (see Table 3). The adsorbed mass for both proteins is consistent with an adsorbed monolayer [15,38,39]. Based on a protein density of 1.15 $\mathrm{g} \mathrm{cm}^{-3}$ [15] , the thickness of the layers on silica at $\mathrm{pH} 7.4$ would be $16.8 \mathrm{~nm}$ for BGG and $5.1 \mathrm{~nm}$ for $\mathrm{BSA}$ which is consistent with the protein dimensions if proteins adsorbed with an end-on orientation $[15,38]$. BGG adsorption occurs at a higher rate than BSA adsorption. The adsorbed BGG layer is also more rigid in all cases shown by the lower value of $\Delta R / \Delta f$ (see Table 3 ).

The effect of increasing $\mathrm{pH}$ on formation of adsorbed films can be beneficial, giving rise to a thicker film as in the case of chromium surface, or detrimental, as for silica surface. Focusing on final adsorbed mass, this pH effect is most apparent for BGG films on silica, and less apparent on chromium surfaces. An increase of $\mathrm{pH}$ from 7.4 to 8.1 results in a $10 \%$ and $39 \%$ reduction in adsorbed mass for BSA and BGG protein respectively on silica. The maximum adsorption rate is also much reduced as $\mathrm{pH}$ increases (see Table 3). The observations with BSA agree with previous results [5] and a more prominent $\mathrm{pH}$ effect is observed for BGG. In the case of chromium surface, an increase in pH leads to a small increase in adsorbed mass for both BSA (15\%) and BGG (9\%) films. The maximum adsorption rates are also raised by $23 \%$ and $64 \%$ for BSA and BGG films respectively.

While an increase in $\mathrm{pH}$ gives rise to a more viscoelastic BSA films on silica, the viscoelasticity of adsorbed films in all other test cases remains unaffected. This suggests that the nature of BGG film is unaffected by $\mathrm{pH}$. A comparison of the viscoelastic properties of the adsorbed proteins shows BGG forms a more rigid layer than BSA on both silica and chromium surfaces (see Table 3). This is in contrast to Benesch et al. [15] that found BSA adsorbed more rigidly on hydrophilic surfaces. Their finding was at the lower concentration of $1 \mathrm{mg} / \mathrm{ml}$, which may change the orientation and packing of 
proteins [40], and hence the viscoelastic properties of the adsorbed layer. This highlights the importance of conducting adsorption experiments that match the unique conditions of model synovial fluids.

Thicker films have previously been shown to reduce friction, and stiction which can lead to wear [41], Based on the discussion above, BGG films are thicker, can be replenished more quickly (due to high adsorption rate) and are more rigid than BSA films in all test conditions, suggests that a BGG film may provide better protection to rubbing surfaces than BSA films. This may be due to BGG having a higher isoelectric point, hence less negatively charged, than $\mathrm{BSA}$ at both $\mathrm{pH} 7.4$ and 8.1 [42,43]. As a result, the repulsion between BGG and the negatively charged silica and chromium surfaces is lower, giving rise to higher adsorption rate and final adsorbed mass.

It is also shown here that the effect of $\mathrm{pH}$ on protein films formation is surface dependent. At a healthy $\mathrm{pH}$ of 7.4, the mass of protein adsorbed and the rate of adsorption on silica was highest, suggesting that the silica surface may have more wear protection from proteins. The protein films were also more hydrated on silica at lower $\mathrm{pH}$ which has been linked to a lower modulus and lower friction [44]. An opposite and lesser effect is however observed when chromium is used. Hence the thickness of the protein layers and the rate at which they can replenish themselves are reduced (increased) by the increase in $\mathrm{pH}$ suggests that proteins on silica (chromium) will be less (more) effective as a boundary lubricants at the higher $\mathrm{pH}$ [41].

As the rolling tests are conducted between a silica and CoCrMo surface, the impact of $\mathrm{pH}$ may be over emphasized when compared with a metal-on-metal joint as silica is closer to a ceramic surface. However if alumina, which like silica, is charged and hydrophilic also experiences a large reduction in adsorbed protein film thickness, this coupled with alumina's increased dissolution and wear at pH 8.5 in aqueous solutions [45] suggests ceramic-on-ceramic joint performance may be very dependent on a patient's SF pH.

\subsubsection{Protein layer formed in mixed protein solutions}

The effects of $\mathrm{pH}$ on the final mass and adsorption rate of mixed protein films are similar to what has been observed with BGG and BSA films. The strength of the $\mathrm{pH}$ effect differs between silica and chromium surface. In a mixed protein solution, the mass of adsorbed proteins layers on both silica and chromium surfaces are in between that of BSA and BGG layers adsorbed from single protein solutions (see Table 3 ). This suggests that the adsorbed protein layers formed in mixed protein solutions consist of a mixture of BGG and BSA. Assuming that the degree of solvation and the conformation of BGG and BSA on the surface are unaffected by their coexistence, the amount of hydrated BSA in the mixed protein layers is estimated in Table 3. In all cases, hydrated BSA accounts for more than $60 \%$ of the mass of the mixed protein layers. The viscoelasticity of the mixed protein films depends on adsorbed surface and $\mathrm{pH}$. On chromium, the $\Delta R / \Delta f$ ratio of the mixed protein film is close to that of BSA films and is insensitive to $\mathrm{pH}$ (Table 3) ) and hence supports that the mixed protein films are largely made of BSA. This insensitivity to $\mathrm{pH}$ suggests that the nature of the mixed protein layer on chromium does not change in this $\mathrm{pH}$ range and is consistent with observations of 
BSA and BGG layers on chromium. On silica surface, however, the mixed protein film became more viscoelastic as $\mathrm{pH}$ increased. It is rather rigid when $\mathrm{pH}=7.4$ with $\Delta R / \Delta f$ close to that of $\mathrm{BGG}$, while $\Delta R / \Delta f$ increases and is between that of $\mathrm{BGG}$ and $\mathrm{BSA}$ films when $\mathrm{pH}$ is 8.1. This highlights that the interactions between proteins may change depends on experimental condition and cannot be overlooked.

Both the adsorbed mass and rate of adsorption contribute to a reduced film thickness for mixed protein solutions (when compared with BGG solutions) despite the higher protein content. The potentially large amount of BSA in the mixed protein film may also seem contradictory to the observations that at pH 7.4 BGG adsorbs over 5 times (2.4 times) faster than BSA in terms of $\mathrm{ng} / \mathrm{cm}^{2}$ $\mathrm{s}\left(\mathrm{mol} / \mathrm{cm}^{2} \mathrm{~s}\right)$, whilst at $\mathrm{pH} 8.1$ twice (1.03 times) as fast, as shown in Table 3. Note that in a mixed protein solutions, BSA and BGG compete for surface adsorption sites. As listed in Table 1, the mixed protein solution consists of $10(150)$ and $2.4(16) \mathrm{mg} / \mathrm{ml}(\mathrm{nmol} / \mathrm{ml})$ of BSA and BGG respectively. Hence more BSA is available for adsorption. Despite the small amount of BGG in the solutions and in mixed protein films, interactions between BSA and BGG may dominate in some cases, as observed at $\mathrm{pH} 7.4$, where the mixed protein film on silica was rigid.

\subsubsection{Viscoelasticity of protein layers as adsorption progresses}

The change in viscoelasticity of the adsorbed protein films as adsorption progresses can be monitored by correlating $\Delta R / \Delta f$ with $\Delta f$, as shown in Figure 4 . Note these results are before rinsing and so are different to the final value after rinsing given in table 3 . The adsorbed BSA films (dash lines, Figure 4 (a)) and BGG film (dash lines, Figure 4 (b)) on silica were initially viscoelastic, and they became more rigid with further adsorption, i.e. $\Delta R / \Delta f$ decreased with $\Delta f$ became more negative. On chromium, the BGG films were initially viscoelastic and their viscoelasticity increased slightly and quickly reached a plateau (solid lines, Figure 4 (b)). BSA on chromium, on the other hand, initially formed a rigid layer, which became viscoelastic at a critical surface coverage (solid lines, Figure 4 (a)). This behaviour of viscoelasticity transition from rigid to viscoelastic has been observed with the adsorption of BSA on silica in water, but not in Tris saline solutions [5] . In this study, such transition occurs at a lower adsorbed mass on chromium, in particular at lower $\mathrm{pH}$. In all cases examined in this study, the change in $\mathrm{pH}$ does not alter qualitatively the adsorption behaviour of protein films.

For the mixed solutions, the $\Delta R / \Delta f$ of adsorbed mixed protein films on silica at $\mathrm{pH} 8.1$ (dark dash line, Figure 4 (c)) was higher at the initial stage of absorption and decreased slightly as absorption progressed. For mixed protein films on silica at pH 7.4 (light dash line, Figure 4 (c)) and on chromium in both $\mathrm{pH}$ (solid lines, Figure 4 (c)), $\Delta R / \Delta f$ increased with absorbed mass and eventually plateaued.

\subsection{Film Formation in Rolling Contacts}

The measured film thickness with time in a rolling contact formed by a CoCrMo ball against a silica disc is shown for all protein solutions in Figure 5. For BSA solutions the behaviour is dependent on the solution $\mathrm{pH}$ (see Figures 5 (a)). At pH 7.4 the measured film thickness fluctuated over time, between a maximum of $45 \mathrm{~nm}$ and a minimum of $5 \mathrm{~nm}$. At pH 8.1 a thin film was measured at the 
beginning of the test, with a thickness of approximately $8 \mathrm{~nm}$. During rolling the film showed a drop in thickness with much fewer fluctuations observed at the lower $\mathrm{pH}$.

In contrast, the BGG solutions show similar behaviour at both pH 7.4 and 8.1 (Figure 5 (b)). The film thickness increases for the first 300-500 seconds of rolling. After this time a thick, but non-uniform film is formed in the rolling track (see also Figure 6 (I)) which reaches an average thickness of around 250 $\mathrm{nm}$. The measured film thickness fluctuates with time, which suggests disruption and replenishment of the film.

The film thickness measurement with mixed protein solution in rolling contact shows observations similar to those obtained with BSA solution. This is consistent with estimates in section 3.1.2 that the adsorbed mixed protein layers consist mainly of BSA. The mixed protein solutions give rise to films with thickness ranging 20 to $40 \mathrm{~nm}$ (Figure 5 (c)), which is slightly thicker than the film formed in BSA solution. The film thickness at $\mathrm{pH} 7.4$ is larger and with greater fluctuations than films formed at $\mathrm{pH}$ 8.1.

Optical interferometry allows local film thickness to be observed as variations in colour (or grayscale). A region will homogenous thickness will be of one single colour; otherwise the region will compose of domains or strips of various colours. Images taken of the rolling contact show the protein films formed in the contact can be heterogeneities (Figure 6). At pH 7.4, films formed in BSA solutions are fairly homogeneous (light yellow in Figures 6 (a), (b) and (c)), the small increase in film thickness occurring with time visible as a slight darkening in colour. Occasionally, some thick, globular deposits form and are distributed randomly across the contact (Figure 6 (c)). The random fluctuations in the average film thickness (see Figure $5(\mathrm{a})$ ) are due to occasional sampling of these deposits. At pH 8.1 the BSA film was more uniform across the contact, indicating a thin and relatively stable film (see in Figures 6 (d), (e) and (f)).

BGG solutions at $\mathrm{pH} 7.4$ and 8.1 form thick, heterogeneous films across the contact area, as shown in Figures $6(\mathrm{~h}),(\mathrm{i}),(\mathrm{k})$ and $(\mathrm{l})$. Variations in fringe colours across the contact show this film is not homogeneous. Thick bands of protein deposits can be seen across the central part of the images after approximately 5 minutes of rolling (highlighted in Figure $6(\mathrm{I})$ ). These deposits are on top of a relatively thick film (green in Figure $6(\mathrm{~h})$ ). This band extends across and beyond the circular contact area and along the rolling track. This suggests that the protein aggregates, once formed, survive the rolling contact and adhere to the CoCrMo ball.

In the mixed protein solutions, large protein deposits are found (Figures $6(n),(0)$ and (q)) but these do not cover the whole contact as in BGG solution. As a result, large variations in film thickness within the contact are observed, with a thin protein film present in some regions (light yellow, Figures $6(p)$ ). The average thickness of mixed protein film is thicker than that of BSA films. There is some impact of $\mathrm{pH}$ with films formed at $\mathrm{pH} 8.1$ being thinner than those at $\mathrm{pH} 7.4$.

For all solutions the average film thickness after static adsorption $\left(h_{t=0}\right), 1200$ seconds rolling $\left(h_{t=1200}\right)$, and unloading and reloading $\left(h_{\text {final }}\right)$ are compared in Figure 7. $h_{t=0}$ is thickest for BGG films, reducing in order of $\mathrm{BGG}>$ mixed protein $\mathrm{pH} 7.4>\mathrm{BSA}>$ mixed protein at $\mathrm{pH}$ 8.1. The effect of $\mathrm{pH}$ on $h_{t=0}$ in 
BSA and BGG solutions is weak and a slightly stronger effect is observed in mixed protein solutions. $h_{t=1200}$ is greater at $\mathrm{pH} 7.4$ than at $\mathrm{pH} 8.1$ for all solutions. The average film thickness decreases in order of BGG $(237-272 \mathrm{~nm})>$ mixed $(21-35 \mathrm{~nm})>$ BSA solutions $(3-11 \mathrm{~nm})$, despite the total concentration of proteins being higher in the mixed protein solutions than the BGG solutions.

A residual deposited film (see $h_{\text {final }}$ in Figure 7 ) is left on the surface for all solutions, but this is again thickest for BGG solutions. This is confirmed by optical images of the ball surface after testing (Figure 8). For $h_{\text {final, }}$ the change in $\mathrm{pH}$ does not give a statistically significant effect for any protein solution. It is of note that in BGG solution and mixed protein solutions, the film thickness after unloading and reloading $h_{\text {final, }}$, although thinner than the film after rolling for 1200 seconds $h_{t=1200}$, is always thicker than film after static adsorption $h_{t=0}$. This suggests that the films formed during rolling in these two solutions are mechanically stable and stayed in the contact. On the other hand, $h_{\text {final }}$ is of similar thickness to $h_{t=0}$ in BSA solutions, implying that the BSA films deposited during roller can be removed or destroyed easily.

After the test, the ball surface was lightly rinsed with water, dried and observed under a microscope. Typical images are shown in Figure 8. For BSA at pH 7.4 some irregular deposits were observed in the contact path (Figure $8(a)$ ). These deposits correspond to the deposits occasionally observed during the imaging tests (Figures 6 (b) and (c)). At pH 8.1, BSA forms thinner, sparse deposits (Figures $6(\mathrm{~d})$ ). Much thicker BGG deposits were observed on the ball surface at both $\mathrm{pH}$ in the form of bands on the rolling track (Figures 8 (b) and (e)). These bands showed some variations with thicker clumps and thinner areas which accounts for the fluctuation in the film thickness measurements (Figure 5 (b)). A band of deposited film is also formed for mixed protein solutions. The band is formed of thin pale areas and thicker, irregular globular deposits (Figure 8 (c)). The thicker globular deposits are observed more often at $\mathrm{pH} 7.4$, and would result in the increased fluctuations observed in the film thickness measurements at the lower pH (Figure 5 (c)).

\subsection{Comparison of films formed statically and under rolling}

Both static adsorption results from QCM (section 3.1) and rolling test results (section 3.2) show that the average film thickness in protein solutions in order of thickest to thinnest is BGG > mixed > BSA solutions. This is consistent with results which showed BGG formed the thickest films and offered improved wear protection over both BSA [10,11] and BCS (which contains both BSA and BGG) [11] solutions in sliding tests. Note the protein content of test solutions in this study is $12.4 \mathrm{mg} / \mathrm{ml}, 10$ $\mathrm{mg} / \mathrm{ml}$ and $2.4 \mathrm{mg} / \mathrm{ml}$ in the mixed, BSA and BGG solutions respectively. This highlights that the thickest lubricating film is not simply related to the protein content of the solution, but is dependent on the particular combination of proteins in the solution. In particular the addition of BSA to the BGG solution may inhibit the formation of thick BGG films through processes such as macromolecular crowding. In solution, macromolecular crowding has been shown to alter the rates of aggregation of large proteins [46] such as BGG. This result also supports the findings of Brandt et al. [47] who demonstrate that matching total protein content is not sufficient to replicate SF behaviour, and that the concentrations of individual proteins are important. This result also suggests that patients with 
synovial fluid with low amounts of gamma-globulin are likely to see increased wear of metal and ceramic hip prosthesis.

Using the adsorbed mass from QCM, the protein film thickness on silica surface $\left(h_{S_{i}}\right)$ and chromium surface $\left(h_{c r}\right)$ was calculated based on a protein density of $1.15 \mathrm{~g} / \mathrm{cm}^{3}$ [15]. These were then used as an estimation of the film thickness in a static contact $h_{\text {static; }}$ i.e. $h_{\text {static }}=h_{S i}+h_{C r}$. In Figure $9, h_{\text {static }}$ is compared with $h_{t=0}$, i.e. the film thickness measured by optical interferometry in a static contact after protein was allowed to adsorb on the surfaces. The same overall trend is observed for $h_{\text {static }}$ and $h_{t=0}$. However the measured film thickness $h_{t=0}$ is always less than $h_{\text {static }}$ by around $70 \%$. In addition the differences among $h_{t=0}$ for different solutions are small compared to the differences in $h_{\text {static }}$. This could be either a result of a combination of (1) the protein layers deforming under load, (2) squeezing water or proteins out of the contact, or (3) differences in protein adsorption on chromium and CoCrMo surfaces.

The results presented in Figure 9 suggest that properties of films formed in static equilibrated conditions (as in QCM measurements), whilst different from films in a loaded tribological contact, may still be related. As the film formed under rolling is between both a silica and CoCrMo surface, $h_{t=1200}$ can be governed by the properties of adsorbed film on $\mathrm{Cr}$, on silica, or both. To investigate this hypothesis, $h_{t=1200}$ was plotted against QCM results for final adsorbed mass, maximum adsorption rate and final viscoelastic response on (1) silica, (2) chromium and (3) an average of the results for both surfaces. Note that QCM results demonstrated the properties of adsorbed films were different on silica and chromium surfaces. The goodness of fit, $R^{2}$ values, as given in Table 4 shows that the film thickness during rolling is most closely correlated with the average properties of adsorbed films on silica and chromium surface, This demonstrates that the interaction of proteins with each of these surfaces influences the formation of the lubricating film. The correlation shown between properties of adsorbed films and lubricating films, as shown in Figure 10, suggests the adsorbed films may contribute to the agglomerated films in the contact inlet. Alternatively, the distribution of proteins on the surface may reflect how the proteins are distributed in the bulk solution. More explicitly, if the proteins are more closely packed on the surface, the repulsion between proteins is lower so that increased aggregation can occur in the bulk solution [47]. The correlation between viscoelastic properties and film thickness indicates that increased hydration results in thinner films, and can be related to a reduction in the compressive modulus [48]. Figure 10 demonstrates that whilst there is a strong correlation, further work with mixed solutions with different BSA:BGG ratios would improve understanding of this relationship..

\section{Conclusion}

Films formed from protein solutions either statically or under rolling are dependent on the protein content and solution $\mathrm{pH}$. Under rolling, protein layers are much thicker than statically adsorbed layers. These thick deposited layers are consistent with the previously reported protein aggregation lubrication mechanism $[8,9]$. Comparing the film thickness during rolling test, $h_{t=1200}$, and after the 
test, $h_{\text {final }}$ shows the deposited films formed by BGG and mixed proteins during rolling are quite strongly bound, while for BSA films, it is only weakly bound.

Of the two proteins BSA and BGG, BGG forms much thicker deposited layers. When the proteins are combined, the ability of BGG to form thick layers is reduced demonstrating that the interaction of the proteins changes the process of film formation and the lubricating film thickness does not correlate with protein concentration alone. This calls into question the use of BCS as a model synovial fluid, which is matched for total protein concentration, but not relative amounts of proteins such as BSA and BGG.

Although the final structure of statically adsorbed films and those formed under rolling are very different, the properties of films formed in the two test conditions can be correlated. This may allow adsorption results to be used to predict lubricating film thickness, which is known to indicate wear performance [11].

\section{Acknowledgements}

The authors wish to thank the UK EPSRC for funding this research: "In Contact Analysis of Synovial Fluid Lubricating Film Properties" (EP/H020837/1) and Platform Grant "Nanotribology: Measurement and Modelling across the Rubbing Interface" (EP/G026114/1).

[1] Philpott a, Weston-Simons JS, Grammatopoulos G, Bejon P, Gill HS, McLardy-Smith P, et al. Predictive outcomes of revision total hip replacement--a consecutive series of 1176 patients with a minimum 10-year follow-up. Maturitas 2014;77:185-90.

[2] Smith AJ, Dieppe P, Howard PW, Blom AW. Failure rates of metal-on-metal hip resurfacings: analysis of data from the National Joint Registry for England and Wales. Lancet 2012;380:1759-66.

[3] Lavernia C, Lee DJ, Hernandez VH. The Increasing Financial Burden of Knee Revision Surgery in the United States. Clin Orthop Relat Res 2006;446.

[4] Oates KMN, Krause WE, Jones RL, Colby RH. Rheopexy of synovial fluid and protein aggregation. J R Soc Interface 2006;3:167-74.

[5] Parkes M, Myant C, Cann PM, Wong JSS. The effect of buffer solution choice on protein adsorption and lubrication. Tribol Int 2013.

[6] Cummings N, Nordby G. Measurement of synovial fluid pH in normal and arthritic knees. Arthritis Rheum 1966;9.

[7] Blewis ME, Nugent-Derfus GE, Schmidt T a, Schumacher BL, Sah RL. A model of synovial fluid lubricant composition in normal and injured joints. Eur Cell Mater 2007;13:26-39.

[8] Myant C, Cann P. On the matter of synovial fluid lubrication: Implications for Metal-on-Metal hip tribology. J Mech Behav Biomed Mater 2014:1-11. 
[9] Myant C, Cann P. In contact observation of model synovial fluid lubricating mechanisms. Tribol Int 2012;63:1-8.

[10] Myant C, Underwood R, Fan J, Cann PM. Lubrication of metal-on-metal hip joints: the effect of protein content and load on film formation and wear. J Mech Behav Biomed Mater 2012;6:3040.

[11] Fan J, Myant C, Underwood R, Cann P. Synovial fluid lubrication of artificial joints: protein film formation and composition. Faraday Discuss 2012;156:69.

[12] Vrbka M, Navrat T, Krupka I, Hartl M, Sperka P, Gallo J. Study of film formation in bovine serum lubricated contacts under rolling/sliding conditions. Proc Inst Mech Eng Part J J Eng Tribol 2013;227:459-75.

[13] Vrbka M, Křupka I, Hartl M, Návrat T, Gallo J, Galandáková A. In situ measurements of thin films in bovine serum lubricated contacts using optical interferometry. Proc Inst Mech Eng $\mathrm{H}$ 2014;228:149-58.

[14] Vrbka M, Návrat T, Krupka I, Hartl M, Gallo J. mapping of film thickness in bovine serum lubricated contacts. Eng Mech 2013;20:27-41.

[15] Benesch J, Mano JF, Reis RL. Analysing protein competition on self-assembled mono-layers studied with quartz crystal microbalance. Acta Biomater 2010;6:3499-505.

[16] Höök F, Vörös J, Rodahl M, Kurrat R, Böni P, Ramsden J., et al. A comparative study of protein adsorption on titanium oxide surfaces using in situ ellipsometry, optical waveguide lightmode spectroscopy, and quartz crystal microbalance/dissipation. Colloids Surfaces B Biointerfaces 2002;24:155-70.

[17] Petrash S, Cregger T, Zhao B, Pokidysheva E, Foster MD, Brittain WJ, et al. Changes in Protein Adsorption on Self-Assembled Monolayers with Monolayer Order: Comparison of Human Serum Albumin and Human Gamma Globulin. Langmuir 2001;17:7645-51.

[18] Lassen B, Malmsten M. Competitive Protein Adsorption Studied with TIRF and Ellipsometry. J Colloid Interface Sci 1996;179:470-7.

[19] Lassen B, Malmsten M. Structure of protein layers during competitive adsorption. J Colloid Interface Sci 1996;349:339-49.

[20] Green RJ, Davies MC, Roberts CJ, Tendler SJ. Competitive protein adsorption as observed by surface plasmon resonance. Biomaterials 1999;20:385-91.

[21] Lutanie E, Voegel J. Competitive adsorption of human immunoglobulin $\mathrm{G}$ and albumin: consequences for structure and reactivity of the adsorbed layer. Proc ... 1992;89:9890-4.

[22] Malmsten M, Lassen B. Competitive protein adsorption at phospholipid surfaces. Colloids Surfaces B Biointerfaces 1995;4:173-84.

[23] Vörös J. The density and refractive index of adsorbing protein layers. Biophys J 2004;87:55361.

[24] Greene GW, Zappone B, Söderman O, Topgaard D, Rata G, Zeng H, et al. Anisotropic dynamic changes in the pore network structure, fluid diffusion and fluid flow in articular cartilage under compression. Biomaterials 2010;31:3117-28.

[25] McCarty DJ. Synovial Fluid. In: Hollander JL, McCarty DJ, editors. Arthritis Appl. con- ditions A Textb. Rheumatol., Lippincott Williams \& Wilkins; 1989, p. 69-90. 
[26] Scholes SC, Unsworth a. Comparison of friction and lubrication of different hip prostheses. Proc Inst Mech Eng Part H J Eng Med 2000;214:49-57.

[27] Rezwan K, Meier LP, Rezwan M, Vörös J, Textor M, Gauckler LJ. Bovine Serum Albumin Adsorption onto Colloidal Al2O3 Particles: A New Model Based on Zeta Potential and UV-Vis Measurements. Langmuir 2004;20:10055-61.

[28] Wimmer M, Loos J, Nassutt R, Heitkemper M, Fischer A. The acting wear mechanisms on metal-on-metal hip joint bearings: in vitro results. Wear 2001;250:129-39.

[29] Tanaka Y, Saito H, Tsutsumi Y, Doi H, Imai H, Hanawa T. Active Hydroxyl Groups on Surface Oxide Film of Titanium, 316 L Stainless Steel, and Cobalt-Chromium-Molybdenum Alloy and Its Effect on the Immobilization of Poly(Ethylene Glycol). Mater Trans 2008;49:805-11.

[30] Wang A, Essner A, Schmidig G. The effects of lubricant composition on in vitro wear testing of polymeric acetabular components. J Biomed Mater Res B Appl Biomater 2004;68:45-52.

[31] Fredriksson C, Kihlman S, Rodahl M, Kasemo B. The Piezoelectric Quartz Crystal Mass and Dissipation Sensor: A Means of Studying Cell Adhesion. Langmuir 1998;14:248-51.

[32] Martin SJ, Granstaff VE, Frye GC. a Quartz Crystal Microbalance with Simultaneous Mass and Liquid Loading 1991;2281:2272-81.

[33] Frateur I, Lecoeur J, Zanna S, Olsson C-O a., Landolt D, Marcus P. Adsorption of BSA on passivated chromium studied by a flow-cell EQCM and XPS. Electrochim Acta 2007;52:76609.

[34] Stadler $\mathrm{H}$, Mondon M, Ziegler C. Protein adsorption on surfaces: dynamic contact-angle (DCA) and quartz-crystal microbalance (QCM) measurements. Anal Bioanal Chem 2003;375:53-61.

[35] Mavraki A, Cann P. Friction and lubricant film thickness measurements on simulated synovial fluids. Proc Inst Mech Eng Part J J Eng Tribol 2009;223:325-35.

[36] Mavraki A, Cann PM. Lubricating film thickness measurements with bovine serum. Tribol Int 2011;44:550-6.

[37] Underwood RJ, Zografos a., Sayles RS, Hart a., Cann P. Edge loading in metal-on-metal hips: low clearance is a new risk factor. Proc Inst Mech Eng Part H J Eng Med 2012;226:217-26.

[38] Figueira VBC, Jones JP. Viscoelastic study of the adsorption of bovine serum albumin on gold and its dependence on pH. J Colloid Interface Sci 2008;325:107-13.

[39] Zhou C, Friedt J-M, Angelova A, Choi K-H, Laureyn W, Frederix F, et al. Human immunoglobulin adsorption investigated by means of quartz crystal microbalance dissipation, atomic force microscopy, surface acoustic wave, and surface plasmon resonance techniques. Langmuir 2004;20:5870-8.

[40] Kao P, Allara DL, Tadigadapa S. Study of Adsorption of Globular Proteins on Hydrophobic Surfaces. IEEE Sens J 2011;11:2723-31.

[41] Widmer MR, Heuberger M, Vörös J, Spencer ND. Influence of polymer surface chemistry on frictional properties under protein-lubrication conditions : implications for hip-implant design. Tribol Lett 2001;10:111-6.

[42] Peters Jr T. All about albumin: biochemistry, genetics, and medical applications. Academic Press; 1995. 
[43] Pease LF, Elliott JT, Tsai D-H, Zachariah MR, Tarlov MJ. Determination of protein aggregation with differential mobility analysis: application to IgG antibody. Biotechnol Bioeng 2008;101:1214-22.

[44] Roba M, Naka M, Gautier E, Spencer ND, Crockett R. The adsorption and lubrication behavior of synovial fluid proteins and glycoproteins on the bearing-surface materials of hip replacements. Biomaterials 2009;30:2072-8.

[45] Kalin M, Novak S, Vižintin J. Wear and friction behavior of alumina ceramics in aqueous solutions with different $\mathrm{pH}$. Wear 2003;254:1141-6.

[46] Ellis RJ. Macromolecular crowding: obvious but underappreciated. Trends Biochem Sci 2001;26:597-604.

[47] Brandt J-M, Brière LK, Marr J, MacDonald SJ, Bourne RB, Medley JB. Biochemical comparisons of osteoarthritic human synovial fluid with calf sera used in knee simulator wear testing. J Biomed Mater Res A 2010;94:961-71.

[48] Lubarsky G V, Davidson MR, Bradley RH. Hydration-dehydration of adsorbed protein films studied by AFM and QCM-D. Biosens Bioelectron 2007;22:1275-81. 


\section{Tables}

Table 1 Test solution composition

\begin{tabular}{|c|c|c|}
\hline Protein & Buffer & $\mathrm{pH}$ \\
\hline $10 \mathrm{mg} / \mathrm{ml} \mathrm{BSA}$ & & $\begin{array}{l}7.4 \\
8.1\end{array}$ \\
\hline $2.4 \mathrm{mg} / \mathrm{ml} \mathrm{BGG}$ & Tris Saline & $\begin{array}{l}7.4 \\
8.1\end{array}$ \\
\hline $\begin{array}{l}10 \mathrm{mg} / \mathrm{ml} \mathrm{BSA} \\
2.4 \mathrm{mg} / \mathrm{ml} \mathrm{BGG}\end{array}$ & & $\begin{array}{l}7.4 \\
8.1\end{array}$ \\
\hline
\end{tabular}

Table 2. Film thickness test conditions

\begin{tabular}{|l|l|}
\hline Load (Mean contact pressure) & $5 \mathrm{~N}(200 \mathrm{MPa})$ \\
Rolling Speed & $10 \mathrm{~mm} / \mathrm{s}$ \\
Temperature & $22-25^{\circ} \mathrm{C}$ \\
\hline Test Specimens & $19.8 \mathrm{~mm}$ diameter CoCrMo ball \\
& $100 \mathrm{~mm}$ diameter glass disc with Cr/Silica coating \\
\hline
\end{tabular}


Table 3. Changes in mass and viscoelastic response for BSA, BGG and mixed protein solutions on silica and chromium surfaces

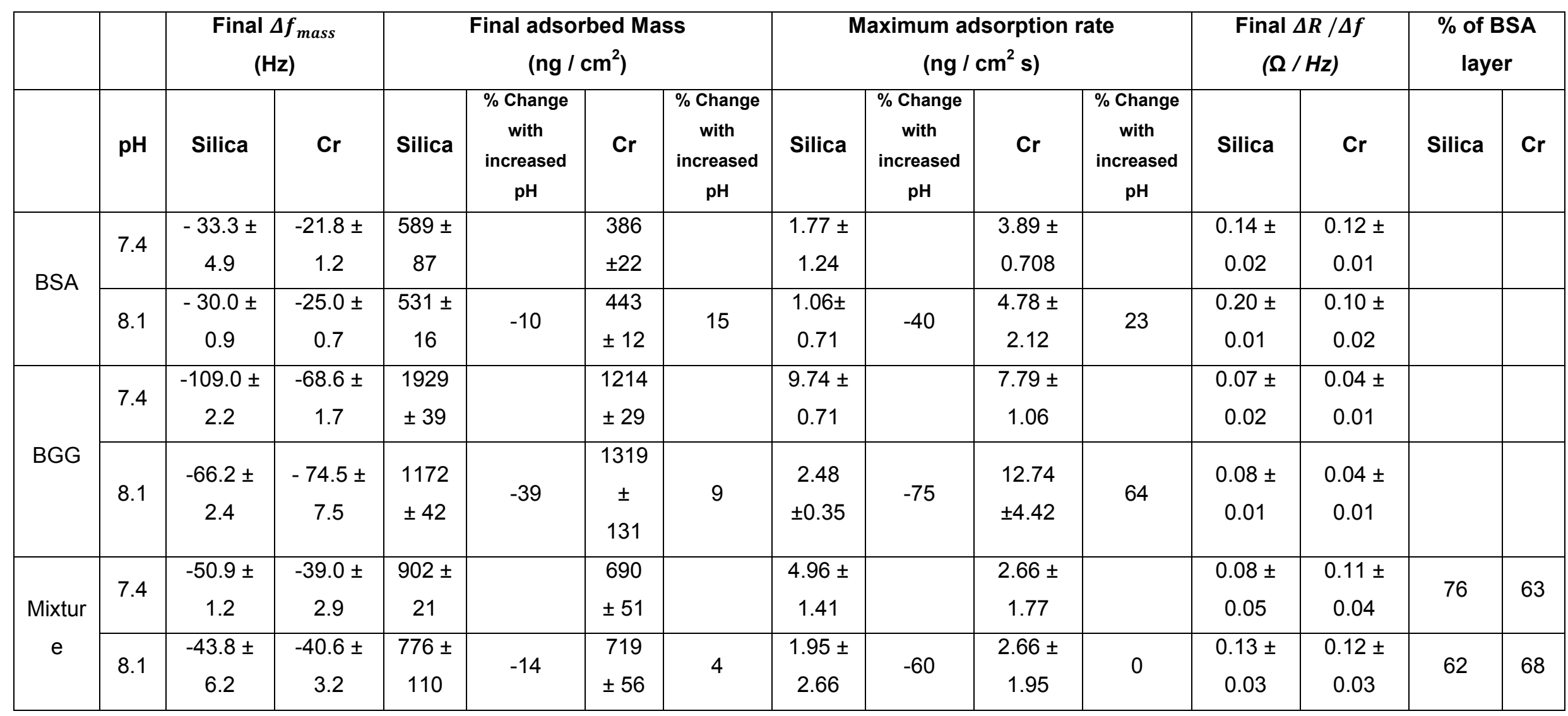


Table 4. $R^{2}$ value for correlation between measured QCM parameters and optical interferometry film thickness

\begin{tabular}{|l|r|r|r|}
\hline & \multicolumn{3}{|c|}{ QCM Surfaces } \\
\cline { 2 - 4 } & Silica & Chromium & Average \\
\hline Adsorbed mass $\left(\mathrm{ng} / \mathrm{cm}^{2}\right)$ & 0.82 & 0.89 & 0.93 \\
\hline Rate $\left(\mathrm{ng} / \mathrm{cm}^{2} \mathrm{~s}\right)$ & 0.45 & 0.69 & 0.97 \\
\hline$\Delta R / \Delta f(\Omega / \mathrm{Hz})$ & 0.54 & 0.94 & 0.87 \\
\hline
\end{tabular}


Figures

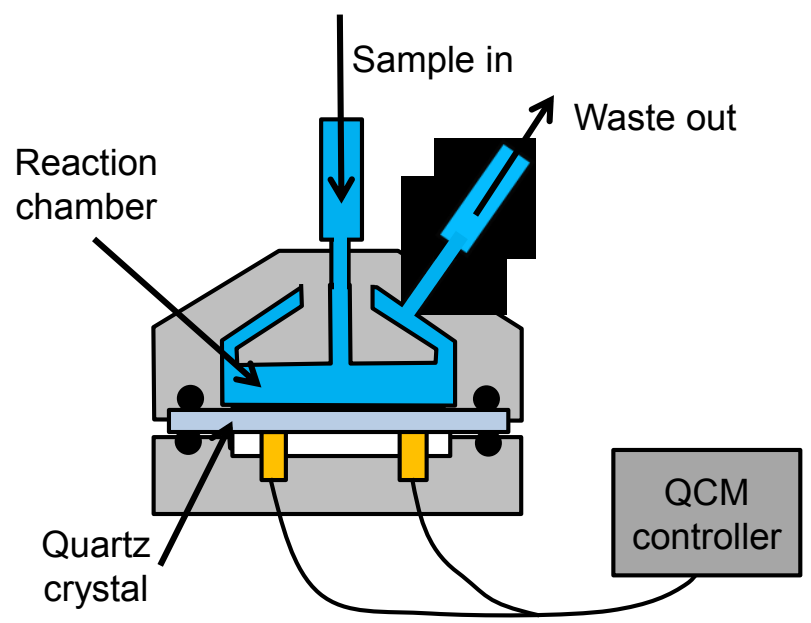

Figure 1. Schematic of QCM with flow cell

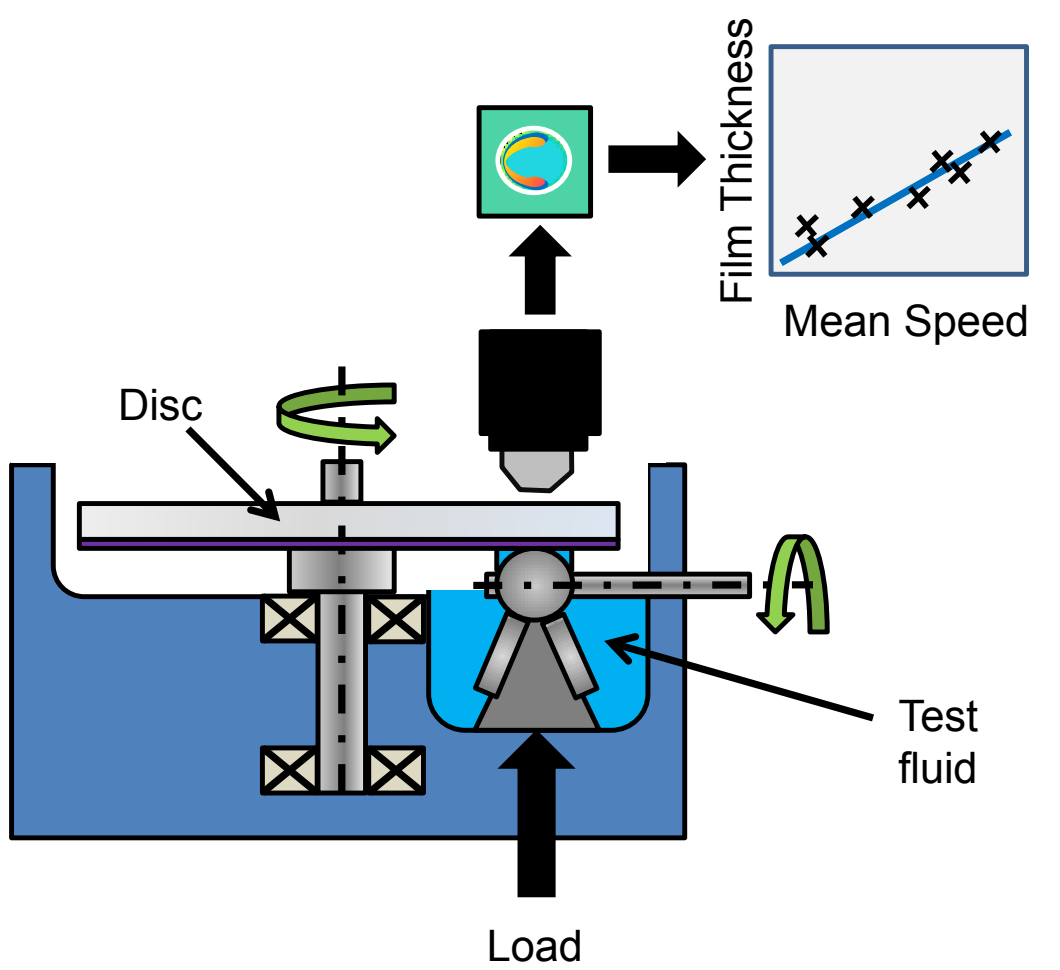

Figure 2. Schematic of rolling setup with optical interferometry 

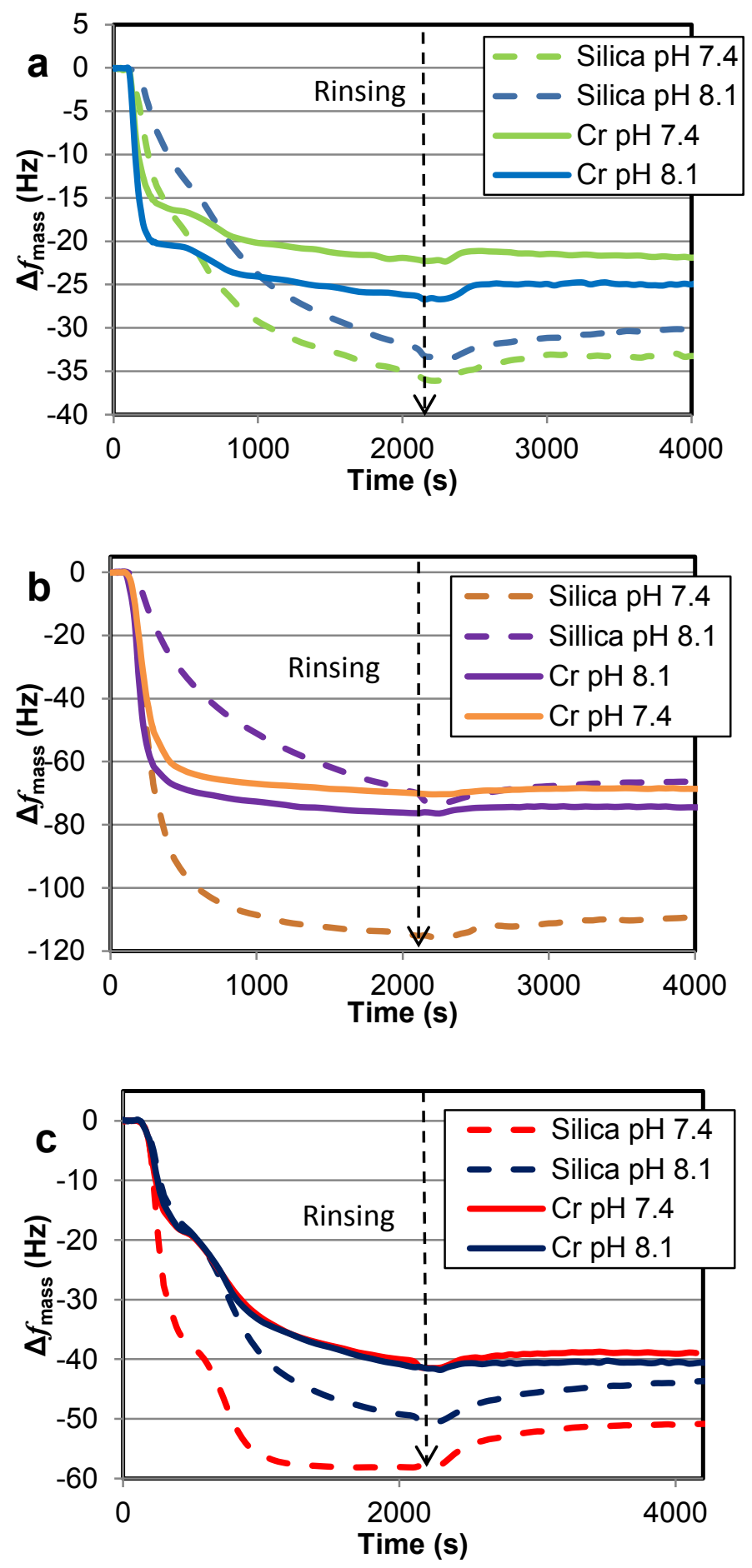

Figure 3 Changes in $\Delta f_{\text {mass }}$ with time for (a) BSA (b) BGG and (c) mixed protein solutions at pH 7.4 and 8.1 on Silica and Chromium surfaces 

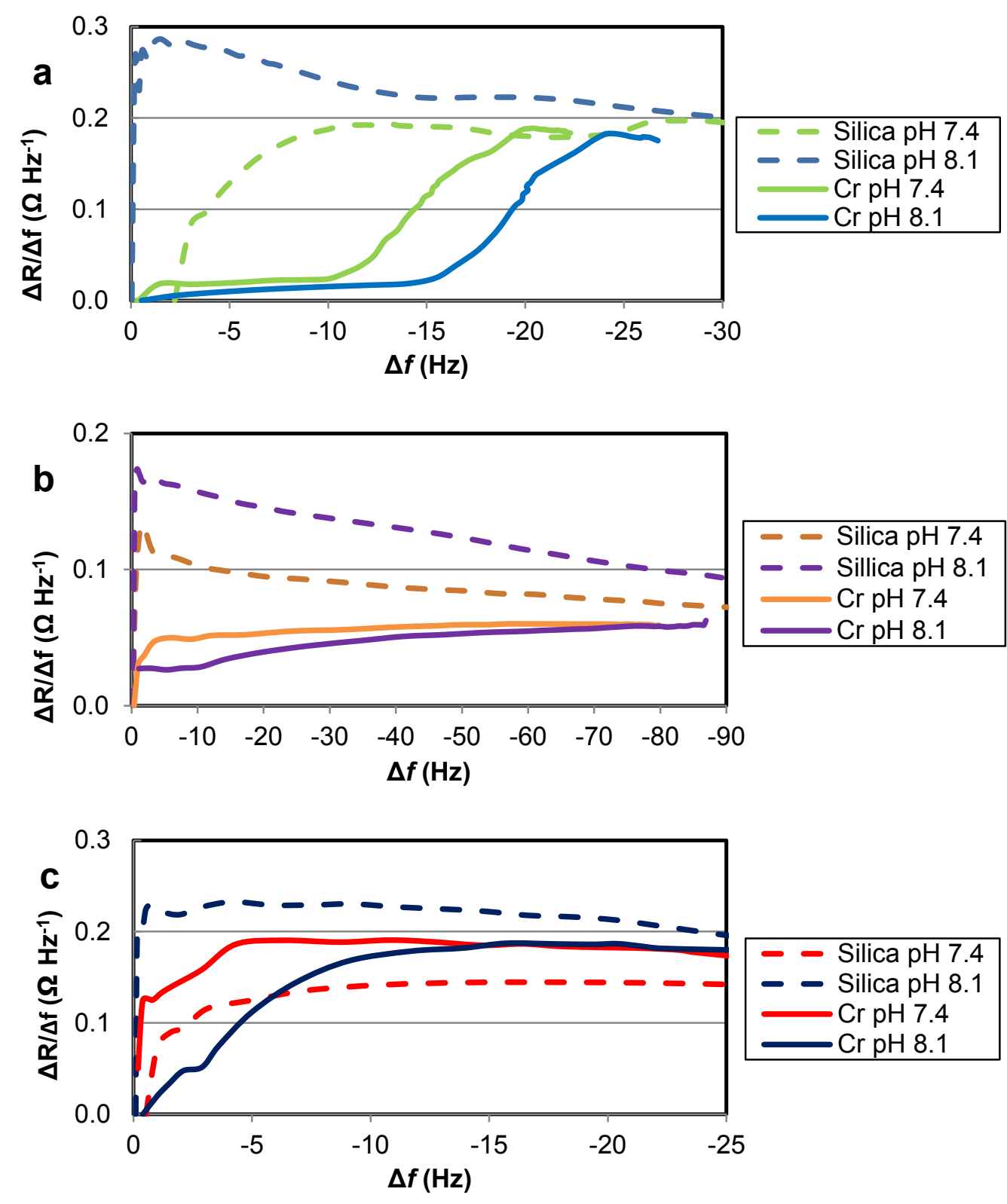

Figure 4 Changes in the ratio $\Delta R / \Delta f$ plotted against changes in frequency for (a) BSA (b) BGG and (c) mixed protein at $\mathrm{pH} 7.4$ and 8.1 on silica and chromium surfaces 


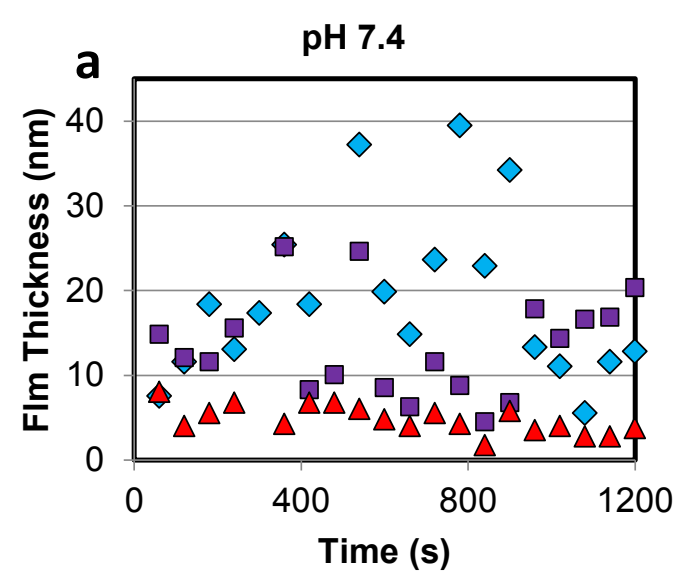

pH 8.1
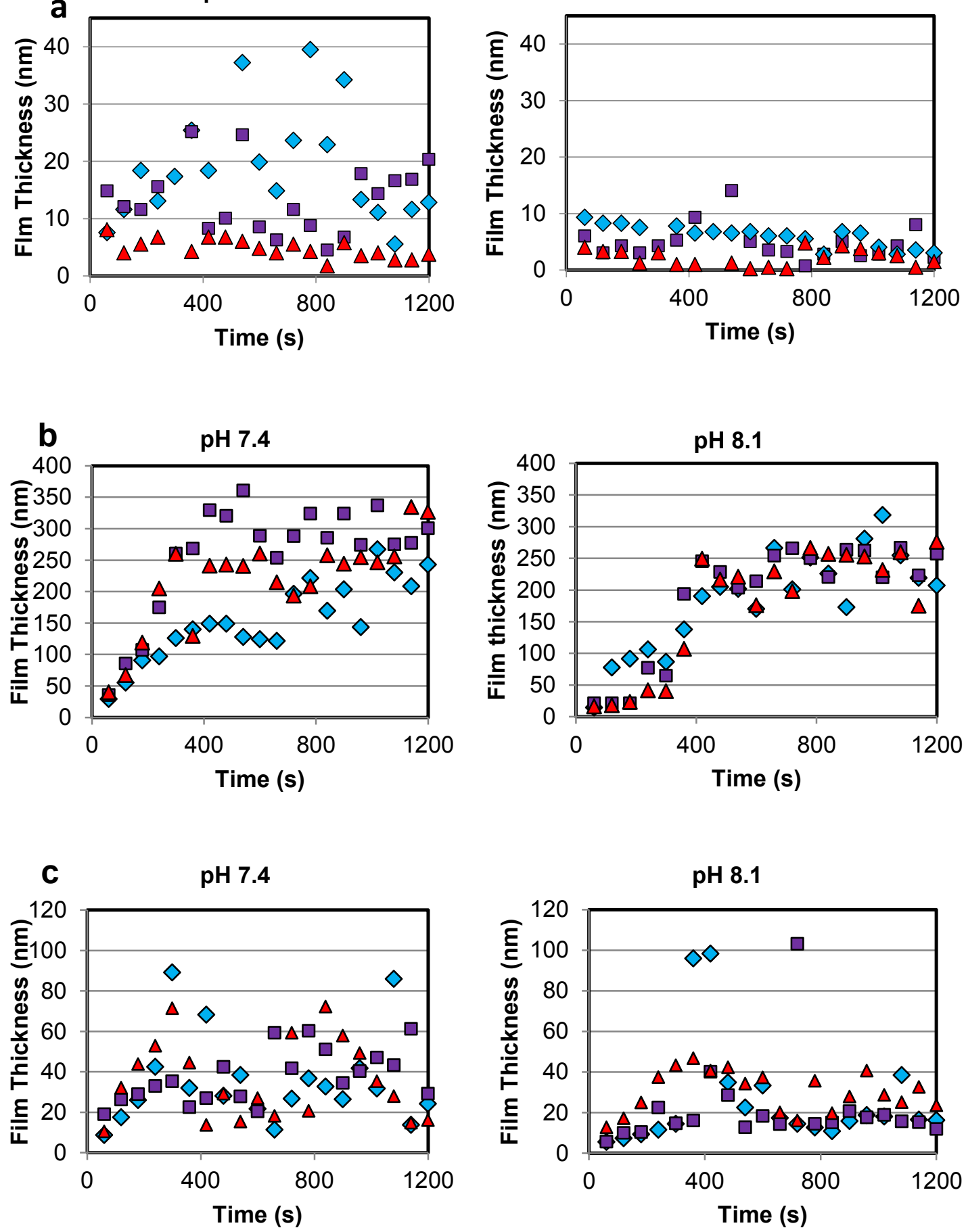

Figure 5 Film thickness results for three tests (different symbols) for (a) BSA (b) BGG and (c) Mixed protein solutions in a rolling contact $(10 \mathrm{~mm} / \mathrm{s})$ at $\mathrm{pH} 7.4$ and 8.1 

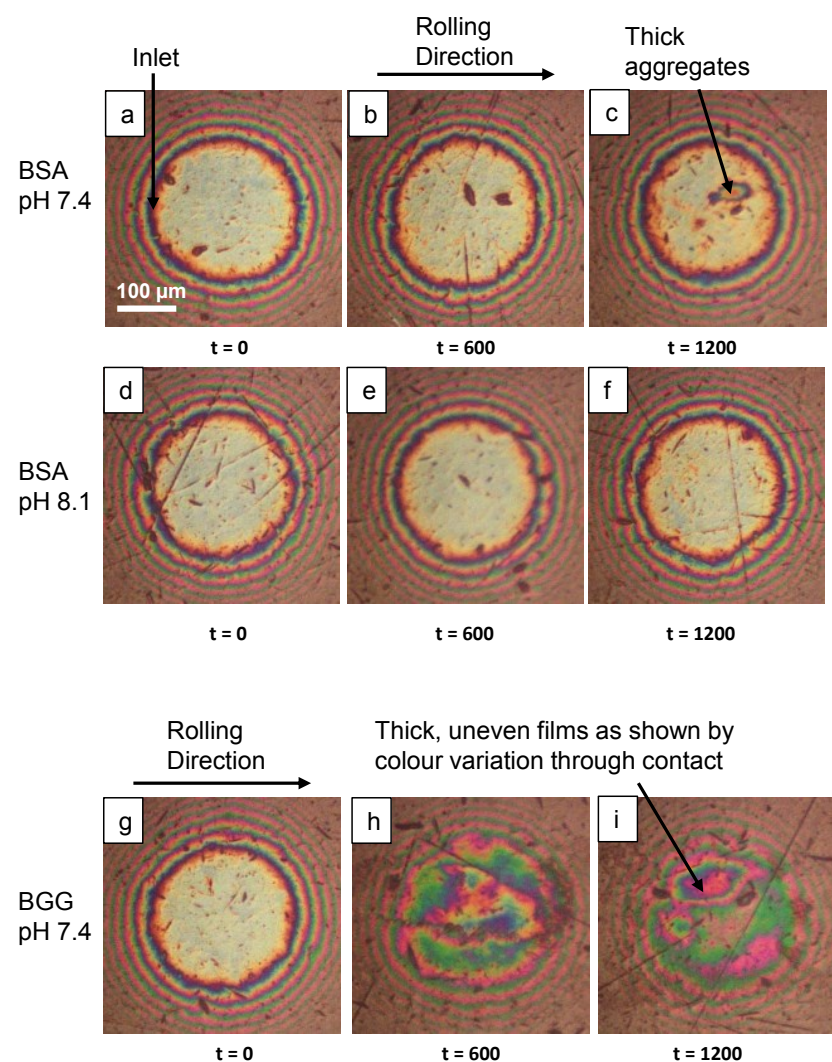

Band of deposited material
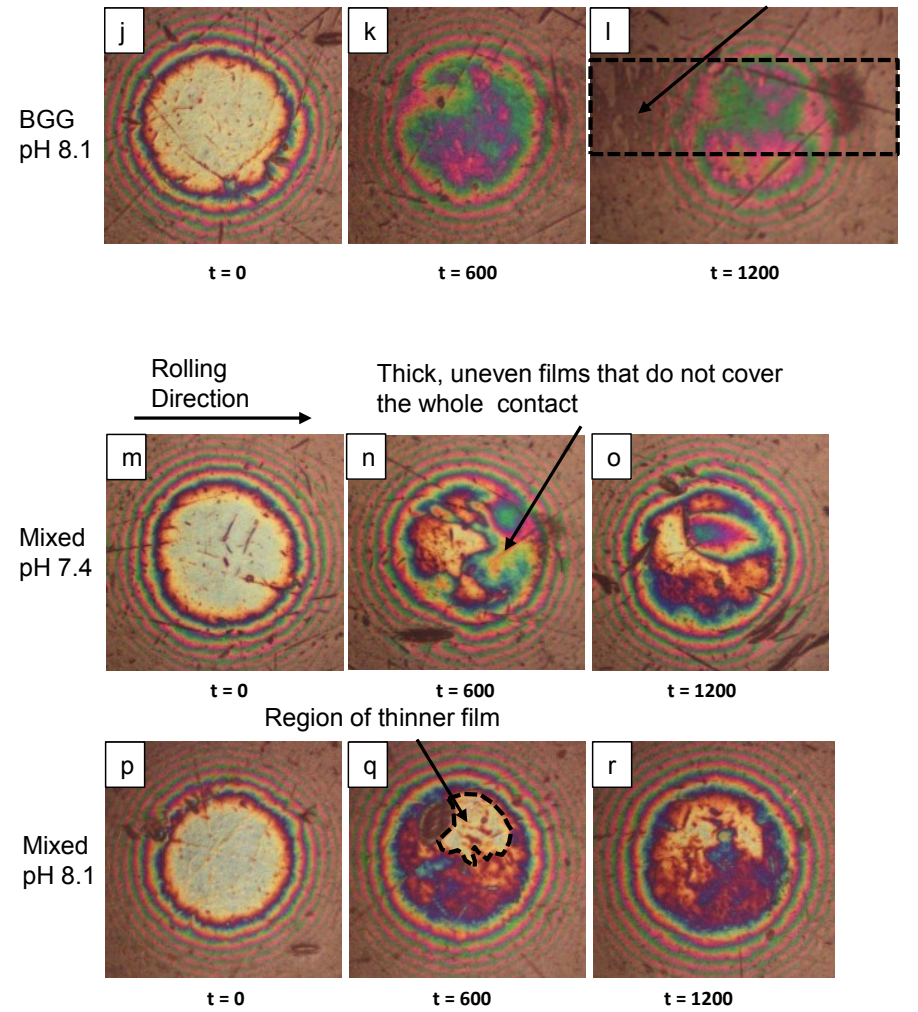

Figure 6 Images taken during rolling at 10x magnification for different protein solutions illustrating the different morphologies of the lubricating films (time $t$ is in seconds). 


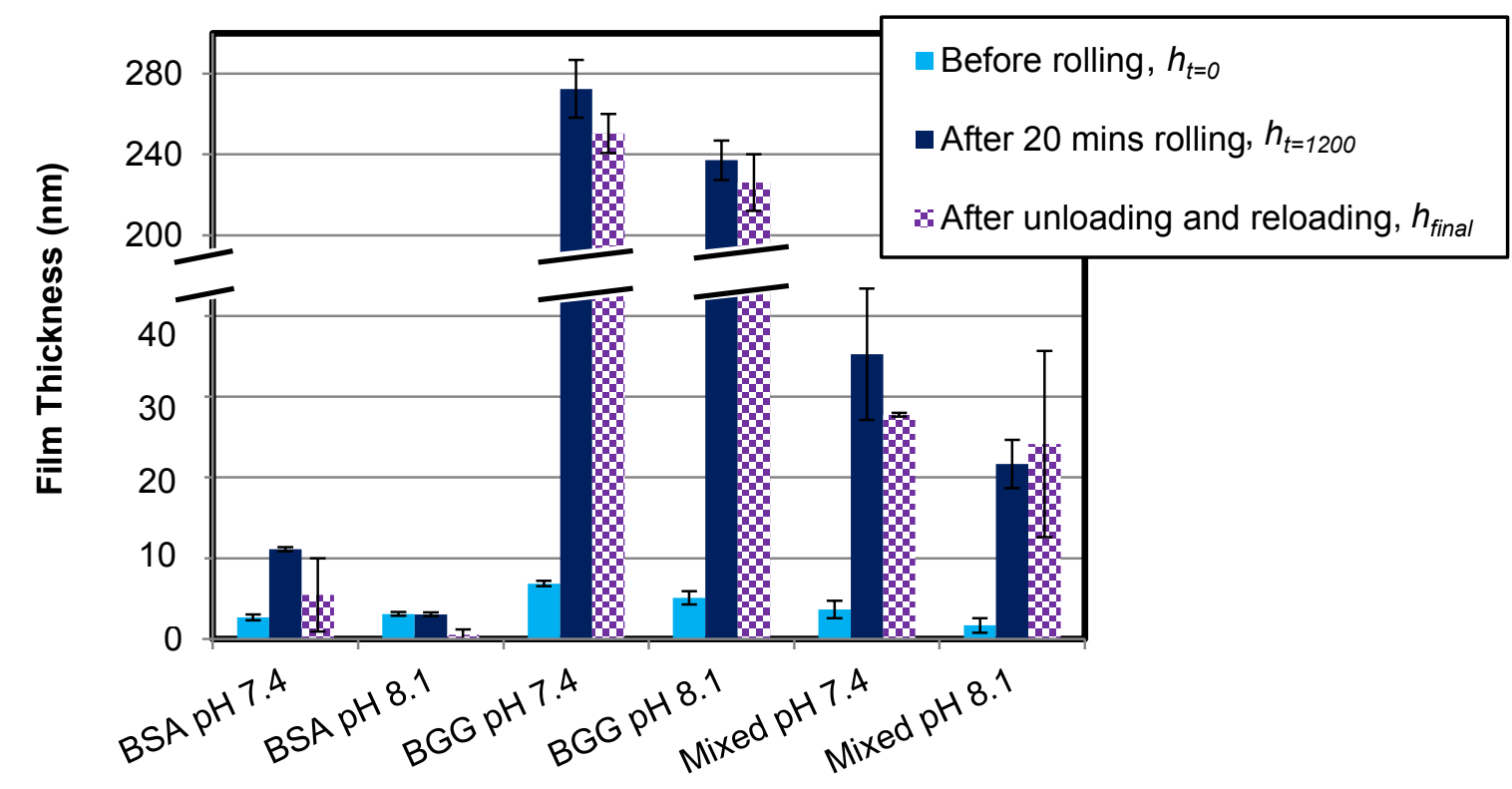

Figure 7 Average measured film thickness for all protein solutions at pH 7.4 and 8.1

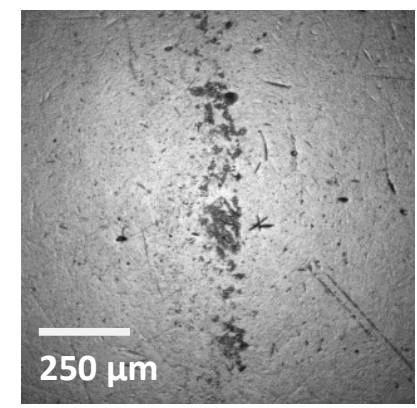

BSA pH 7.4

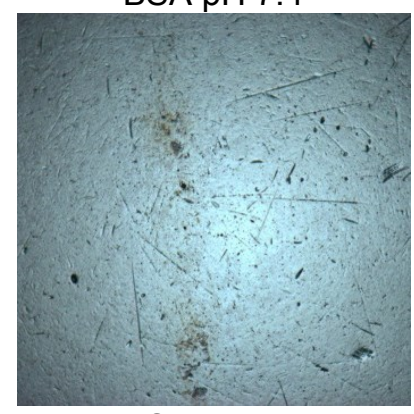

BSA pH 8.1

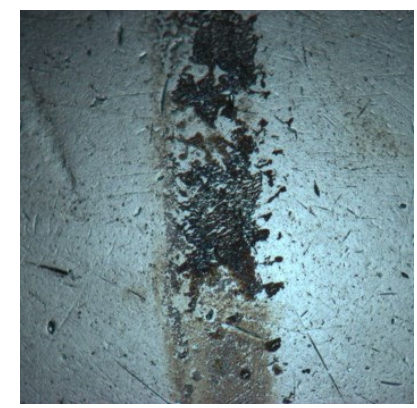

BGG pH 7.4

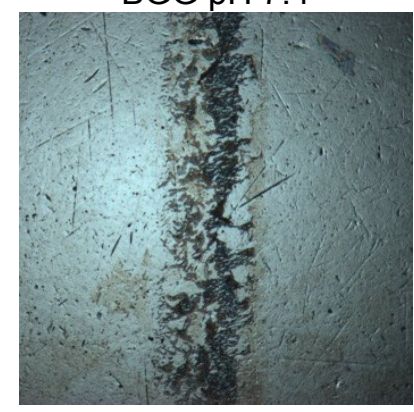

BGG pH 8.1

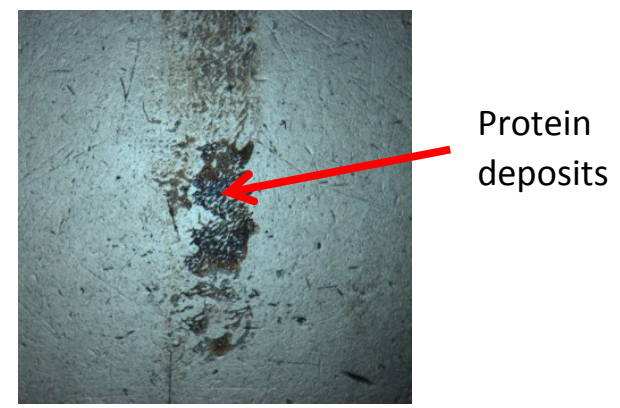

Mixed pH 7.4

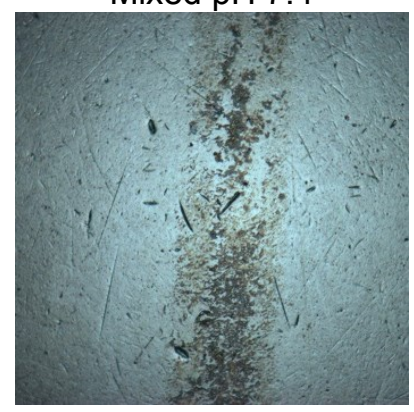

Mixed pH 8.1

Figure 8 Surface deposits on the ball at the end of the test, for all protein solutions. Specimens lightly rinsed with water and air dried. 


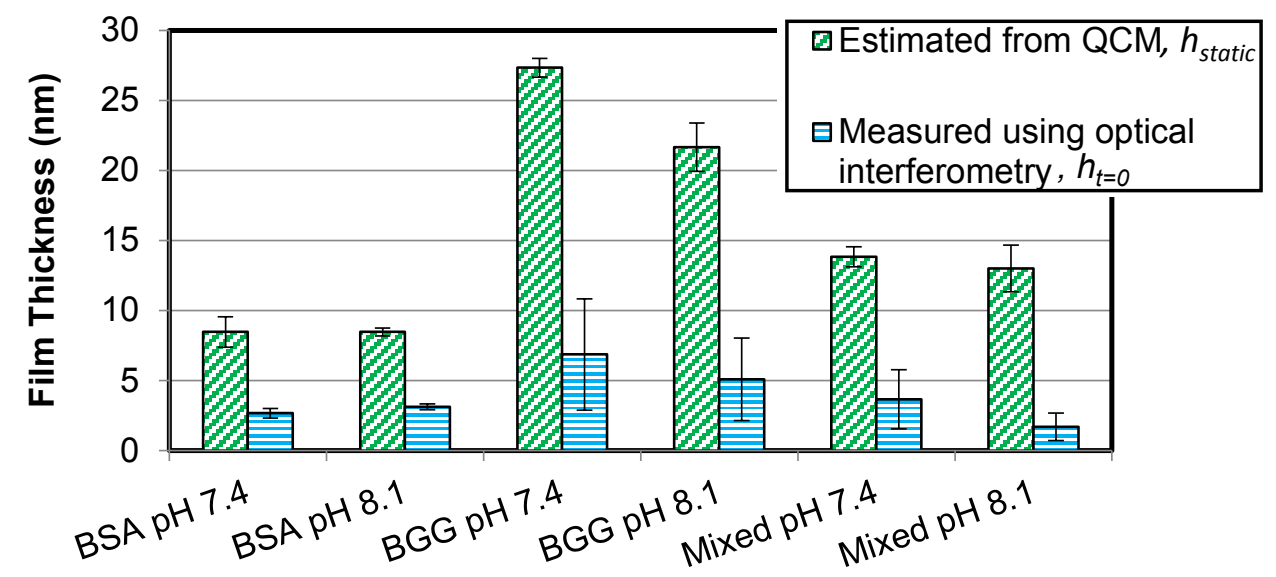

Figure 9 Statically adsorbed film thickness as measured by QCM and optical interferometry for all protein solutions

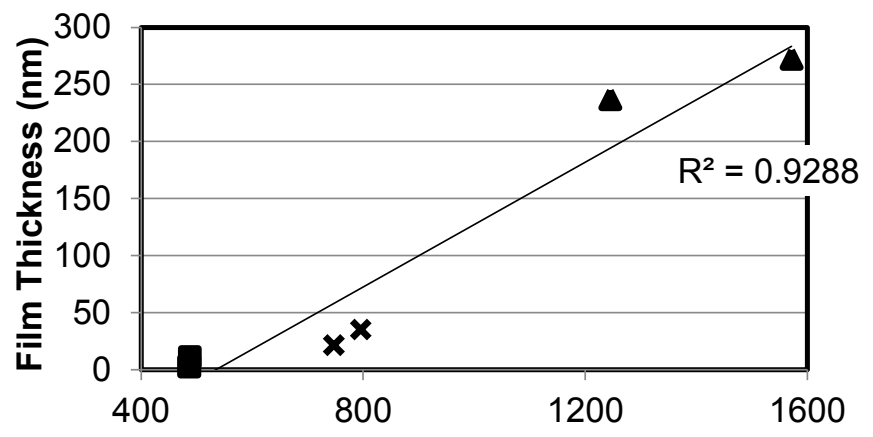

(a) Adsorbed mass (ng/cm2)

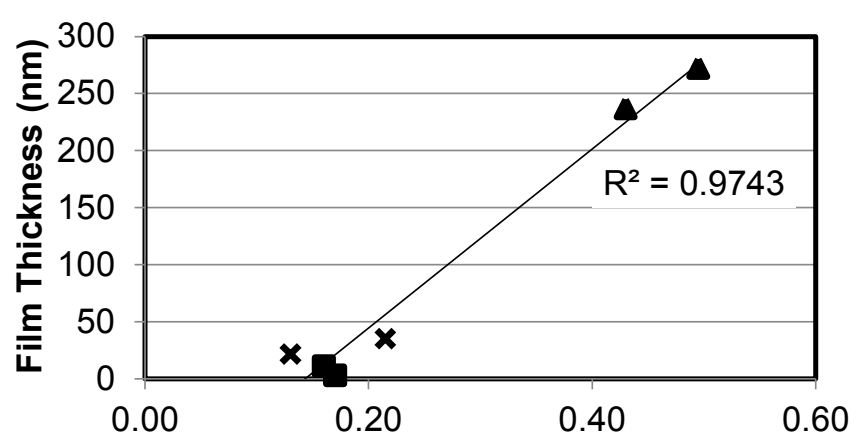

(b) Rate (Hz/s)

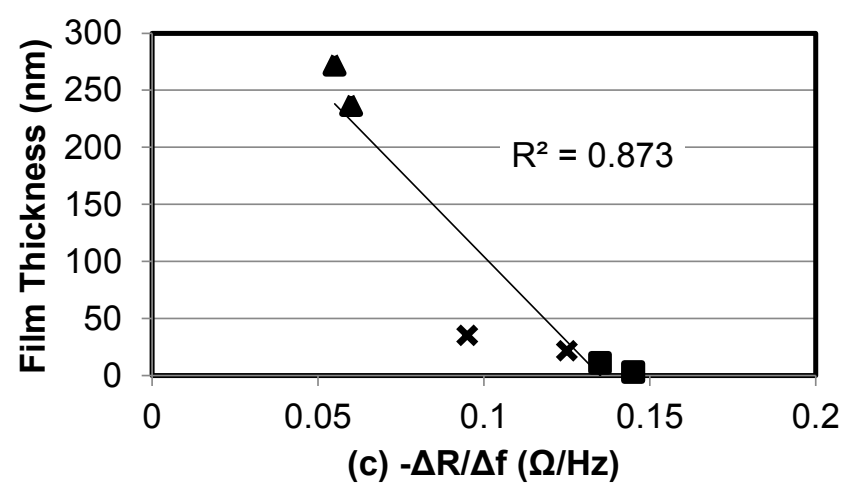


Figure 10 Correlation between the average measured properties from one silica and one chromium surface using QCM and measured film thickness using optical interferometry for BSA ( $\bullet$ ), BGG ( $\mathbf{\Delta}$ ) and mixed protein solutions $(\mathbf{x})$ 